\title{
Atividade Antagonista de Rizobactérias Isoladas de Plantas de Milho Ao Crescimento Micelial e Germinação de Conídios de Fusarium Verticillioides Produtor de Fumonisina B1.
}

Tiago Einloft (I), Flávio Veras (I), Patricia Oliveira (I), Rafael Dionello (I)

(I) UFRGS - Universidade Federal do Rio Grande do Sul (Avenida Bento Gonçalves, 7712, Porto Alegre, Rio Grande do Sul, Brasil)

\section{Resumo}

O Fusarium verticillioides é um fungo que pode gerar grandes perdas por degradar alimentos e produzir Fumonisina B1, uma micotoxina considerada possivelmente carcinogênica para humanos. O controle fúngico é a única maneira de garantir a ausência desta micotoxina. A obtenção de compostos antifúngicos naturais produzidos por bactérias encontradas no solo é uma alternativa interessante na busca por novos conservantes alimentícios naturais. Os objetivos deste trabalho foram: Isolar diferentes bactérias do sistema radicular de plantas de milho, avaliar sua capacidade antifúngica in vitro e testar sua habilidade de inibir a germinação de conídios de F. verticillioides. Amostras de solo rizosférico de plantas de milho foram coletadas na Estação Experimental Agronômica da UFRGS e analisadas através da técnica de diluição em placas. As colônias bacterianas isoladas foram testadas quanto a sua capacidade antagonista e os isolados que demonstraram inibição fúngica foram selecionados. Foi testada a capacidade dos isolados selecionados em inibir o crescimento micelial de F. verticillioides utilizando a técnica de pour plate. Foi realizada a diluição de conídios fúngicos em meio 523 e posteriormente a solidificação, a inoculação de cada isolado bacteriano em três pontos na superfície da placa. Os halos de inibição foram medidos e classificados de acordo com a escala de Bacon \& Hinton. No experimento de redução da germinação de

\footnotetext{
Referência:

Tiago Einloft, Flávio Veras, Patricia Oliveira, Rafael Dionello.Atividade Antagonista de Rizobactérias Isoladas de Plantas de Milho Ao Crescimento Micelial e Germinação de Conídios de Fusarium Verticillioides Produtor de Fumonisina B1.. In: Anais do $12^{\circ}$ Congresso Latinoamericano de Microbiologia e Higiene de Alimentos MICROAL 2014 [= Blucher Food Science Proceedings, num.1, vol.1]. São Paulo: Editora Blucher, 2014. DOI 10.5151/foodsci-microal-069
} 
conídios foram inoculados em poças presentes em lâminas de vidro, suspensões de cada isolado bacteriano e de esporos fúngicos. As lâminas foram incubadas em placas de petri contendo papel filtro umedecido. Após, 300 esporos foram contados para cada tratamento e foi determinada a proporção de esporos germinados. Foram isoladas 688 colônias bacterianas das quais 28 isolados apresentaram atividade antifúngica. Três isolados demonstraram-se superiores aos demais, apresentando o seguinte grau de inibição à distância: RF69: ++; RP103: ++; RP242: +++. Os três isolados demonstraram inibição de 95, 93 e 89\% da germinação de conídios de F. verticillioides, respectivamente. Os resultados apresentados demonstram o potencial de bactérias provenientes de solo rizosférico em produzir compostos antifúngicos naturais extremamente promissores para o desenvolvimento de conservantes com a capacidade de reduzir o crescimento micelial e a germinação de esporos.

Palavras-Chave: Atividade antagonista, Fumonisina B1, Fusarium verticillioides, Milho, Rizobactérias

Agência de Fomento: 